\title{
The role of pyroxenites in the volatile budgets of intra-plate magmas
}

\author{
SALly A GIBSON ${ }^{1}$, JAMES CROSBY ${ }^{1}$, MATTHEW \\ GLEESON $^{1}$ \& CHARLOTTE JACKSON ${ }^{1}$ \\ ${ }^{1}$ Department of Earth Sciences, University of Cambridge, \\ Downing Street, CB2 3EQ, UK. (sally@esc.cam.ac.uk)
}

Intraplate magmas and their cargoes of deep-sourced mantle material provide unparalled insights into the lithological and chemical heterogeneity of Earth's deep interior. Over the past two decades it has become more widely accepted that basalts erupted at ocean islands and continental interiors may contain melts from both pyroxenite and peridotite sources. Little is known, however, about the effect that pyroxenite melting might have on the volatile budgets $\left(\mathrm{H}_{2} \mathrm{O}, \mathrm{F}, \mathrm{Cl}, \mathrm{S}\right.$ and $\left.\mathrm{CO}_{2}\right)$ of the erupted melts.

Our recent SIMS study of mantle peridotite and pyroxenite xenoliths shows that clinopyroxene is the main host of $\mathrm{H}_{2} \mathrm{O}$ and $\mathrm{F}$. The behaviour of these volatiles is systematic relative to major elements but, because $\mathrm{H}$ and $\mathrm{F}$ occupy different sites in the crystal lattice, their concentrations are decoupled from one another. Pyroxenites have a much greater capacity to host volatiles than peridotites and play an important role in global volatile cycles (Gibson et al. 2020). The composition of clinopyroxenes varies according to if the pyroxenites formed by channelized flow of small fraction melts (kimberlites, alkali basalts) in the lithospheric mantle or as 'hybrids' generated by interactions between ancient recycled oceanic crust and surrounding peridotite in the convecting mantle.

We use these new observations to improve constraints on the variations in the volatile contents of intraplate magmas. Our investigations show that variable melting of clinopyroxenes in different mantle reservoirs may account for the wide range of $\mathrm{H}_{2} \mathrm{O} / \mathrm{Ce}$ and $\mathrm{F} / \mathrm{Nd}$ ratios in intraplate magmas (e.g. Hawaii, Galapagos, Azores, Mangaia) that are not readily accountable by different extents of single-stage melting of a peridotite source. 
This abstract is too long to be accepted for publication.

Please revise it so that it fits into the column on one page. 